\title{
Poverty in Pakistan: A Region-Specific Analysis
}

\section{Muhammad Idrees*}

\begin{abstract}
Most of the earlier literature on poverty in Pakistan uses a single poverty line for the whole country or, at most, relies on a rural-urban divide. This segmentation fails to incorporate differences across provinces. This study estimates different poverty lines for the rural and urban segments of each province and region. Its estimated food, nonfood and overall poverty lines show that, with the exception of the capital territory of Islamabad, the urban poverty line is higher in all regions. The estimates of poverty show that, with the exception of Islamabad Capital Territory, rural poverty is much higher than urban poverty in all regions. We find that 25 percent of urban households and nearly 37 percent of rural households fall below the poverty lines we have defined. The study also finds that poverty measured in terms of households ignores household size and thus suppresses poverty figures.
\end{abstract}

Keywords: Poverty, income distribution, welfare, Pakistan.

JEL classification: I30, O15.

\section{Introduction}

Income distribution has always been of great interest to economists and any growth policy that worsens the distribution of income is selfdefeating. ${ }^{1}$ In the context of income distribution, the most deprived segment of society is the income group that lies below the poverty line. The poverty line is defined as a benchmark of the subsistence level: those households that lie below the poverty line are considered 'poor'.

\footnotetext{
${ }^{*}$ Director, School of Economics, Quaid-i-Azam University, Islamabad, Pakistan.

1 A large volume of literature shows that the relationship between inequality and growth is debatable. For example, Neves and Silva (2014) present a comprehensive overview of such studies and conclude that this relationship is not the same for all countries and all periods, given their different circumstances. However, they find that a persistent increase in inequality over a long period hampers economic growth. On the comparison of rich and poor countries, studies such as Forbes (2000), Halter, Oechslin and Zweimüller (2014) and Castelló-Climent (2010) conclude that inequality adversely affects growth in poor countries, but has a positive impact in rich countries.
} 
Poverty remains a central problem in developing countries and especially in Pakistan, where a significant proportion of the population lives below the poverty line. The official estimates of poverty in Pakistan are presented in Figure 1.2 From 2001/02 to 2013/14, poverty declined continuously at an average annual rate of 2.9 percentage points. In 2013, 29.5 percent of the population lived below the poverty line. Put another way, 58 out of every 200 persons were poor and unable to meet their basic requirements.

Figure 1: Trends in poverty in Pakistan

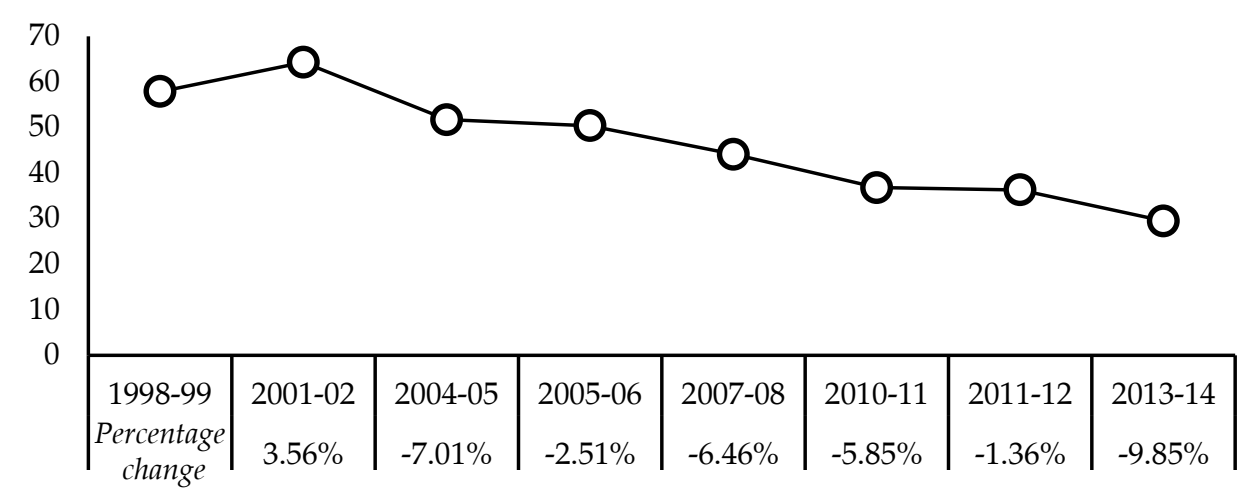

Source: Pakistan Economic Survey, 2015-16.

Clearly, Pakistan must do more to alleviate poverty. More interestingly, the figure of 29.5 percent does not apply equally to all parts of Pakistan: there are large regional disparities. For instance, a rural-urban comparison of poverty reveals that the incidence of poverty is higher in rural areas (see, for example, Anwar \& Qureshi, 2002; Jamal, 2005; Anwar, 2010). The differential within rural and urban areas is also more pronounced across the provinces (Ashraf, 2013).

Since Naseem's (1973) seminal work on poverty in Pakistan, numerous studies have conducted empirical analyses of Pakistani poverty. Most of these have used a single poverty line for the whole country or, at most, relied on a rural-urban divide (see Qureshi \& Arif, 2001; Jamal, 2002, 2005; Jan, Chishti \& Eberle, 2008). This segmentation fails to incorporate differences across provinces. The present study attempts to bridge the gap

\footnotetext{
${ }^{2}$ In 2013/14, the Government of Pakistan revised its methodology for estimating the poverty line and adopted a cost-of-basic-needs approach. The reference group covered households in the second, third and fourth deciles. The headcount indices for previous years were estimated by backcasting this poverty (for details, see Pakistan, Ministry of Finance, 2016).
} 
in the literature by estimating region/province-specific poverty lines. It also estimates different poverty lines for the rural and urban segments of each province and the capital territory of Islamabad. These poverty lines are then used to measure the extent and depth of poverty in each region. The exercise should yield a deeper insight into poverty in Pakistan.

Analyzing poverty with region-specific poverty lines not only gives us more reliable estimates of poverty, but it also helps us understand the dynamics of poverty and thus formulate better policies to alleviate poverty in different regions. Mogstad, Langørgen and Aaberge (2007) also point out that country-specific poverty lines, which neglect regional price differences and assume uniform consumption habits across regions, are more likely to be biased.

The present study uses the latest data from the Household Integrated Economic Survey (HIES) for 2013/14. The HIES is conducted regularly by the Pakistan Bureau of Statistics and contains comprehensive information on income and expenditures at the household level. The HIES for 2013/14 consists of 17,989 households with representation from all the provinces and the federal capital territory.

The study is divided into five sections. Section 2 reviews earlier work on the estimation of poverty lines and measurement of poverty in Pakistan. Section 3 discusses the analytical framework and methodological issues related to estimating poverty lines and measuring poverty. The article's results are given in Section 4 and its conclusion in Section 5.

\section{Literature Review}

Among the numerous contributors to the large body of literature on poverty lines in Pakistan are Naseem (1973) and Alaudin (1975). Although the poverty lines they propose are arbitrary, this was an important step at the time and helped ascertain a standard of poverty measurement despite the use of less scientific research methodologies. Following in their footsteps, De Kruijk and Van Leeuwen (1985), Zaidi (1992) and others have specified relatively arbitrary poverty lines either in terms of expenditure or income for rural and urban areas of Pakistan.

Naseem (1977) arrives at a more scientific approach, the calorie intake approach, which offers relatively more realistic poverty line figures. However, his approach focuses on nutritional needs alone and assumes that households that can barely meet their nutritional requirements also 
consume nonfood items, or else they would have increased their calorie intake. Irfan and Amjad (1984), Ahmad (1998), and others also adopt this approach. Table 1 gives a comprehensive summary of earlier studies conducted on the estimation of poverty lines in Pakistan.

Table 1: Summary of poverty lines proposed/estimated by different studies in Pakistan

\begin{tabular}{|c|c|c|c|}
\hline Approach/study & Unit of analysis & Region & Period of analysis \\
\hline \multicolumn{4}{|l|}{$\begin{array}{l}\text { Arbitrary } \\
\text { benchmarks }\end{array}$} \\
\hline Naseem (1973) & Per capita & $\begin{array}{l}\text { Rural and urban } \\
\text { Pakistan }\end{array}$ & $\begin{array}{l}1963 / 64,1966 / 67 \\
1968 / 69,1969 / 70\end{array}$ \\
\hline Alaudin (1975) & Per capita & $\begin{array}{l}\text { Rural and urban } \\
\text { Pakistan }\end{array}$ & $\begin{array}{l}1963 / 64,1966 / 67 \\
1968 / 69,1969 / 70\end{array}$ \\
\hline $\begin{array}{l}\text { De Kruijk and Van } \\
\text { Leeuwen (1985) }\end{array}$ & Household & $\begin{array}{l}\text { Rural and urban } \\
\text { Pakistan }\end{array}$ & $1969 / 70,1979$ \\
\hline $\begin{array}{l}\text { Ahmad and } \\
\text { Ludlow (1989) }\end{array}$ & Per capita & $\begin{array}{l}\text { Rural and urban } \\
\text { Pakistan }\end{array}$ & $\begin{array}{l}\text { 1976/77, 1979, } \\
1984 / 85\end{array}$ \\
\hline Zaidi (1992) & Adult equivalents & Overall Pakistan & $1984 / 85$ \\
\hline $\begin{array}{l}\text { Zaidi and De Vos } \\
\text { (1993) }\end{array}$ & Adult equivalents & Overall Pakistan & $1987 / 88$ \\
\hline Anwar (2005) & Per capita & $\begin{array}{l}\text { Rural and urban } \\
\text { Pakistan }\end{array}$ & $2001 / 02$ \\
\hline \multicolumn{4}{|l|}{ Calorie intake } \\
\hline Naseem (1977) & Per capita & $\begin{array}{l}\text { Rural and urban } \\
\text { Pakistan }\end{array}$ & $\begin{array}{l}1963 / 64,1966 / 67 \\
1968 / 69,1969 / 70 \\
1970 / 71,1971 / 72\end{array}$ \\
\hline $\begin{array}{l}\text { Irfan and Amjad } \\
(1984)\end{array}$ & Adult equivalents & $\begin{array}{l}\text { Rural and urban } \\
\text { Pakistan }\end{array}$ & $\begin{array}{l}1963 / 64,1966 / 67 \\
1969 / 70,1978 / 79\end{array}$ \\
\hline Ercelawn (1990) & Adult equivalents & $\begin{array}{l}\text { Rural and urban areas } \\
\text { of each province }\end{array}$ & $1984 / 85$ \\
\hline $\begin{array}{l}\text { Mahmood et al. } \\
\text { (1991) }\end{array}$ & Adult equivalents & $\begin{array}{l}\text { Rural and urban } \\
\text { Pakistan }\end{array}$ & $1984 / 85$ \\
\hline Jamal (2002) & Per capita & $\begin{array}{l}\text { Rural and urban } \\
\text { Pakistan }\end{array}$ & $\begin{array}{l}1987 / 88,1996 / 97, \\
1998 / 99\end{array}$ \\
\hline Anwar (2006) & Adult equivalents & Overall Pakistan & $2001 / 02$ \\
\hline Jamal (2005) & Per capita & $\begin{array}{l}\text { Rural and urban } \\
\text { Pakistan }\end{array}$ & $2001 / 02$ \\
\hline Jan et al. (2008) & Adult equivalents & Overall Pakistan & $2001 / 02$ \\
\hline \multicolumn{4}{|l|}{ Basic needs } \\
\hline Malik (1988) & Per capita & $\begin{array}{l}\text { Rural and urban } \\
\text { Pakistan }\end{array}$ & $\begin{array}{l}1963 / 64,1966 / 67 \\
1969 / 70,1979, \\
1984 / 85\end{array}$ \\
\hline $\begin{array}{l}\text { Havinga et al. } \\
(1989)\end{array}$ & Adult equivalents & $\begin{array}{l}\text { Rural and urban } \\
\text { Pakistan }\end{array}$ & $1984 / 85$ \\
\hline
\end{tabular}




\begin{tabular}{|c|c|c|c|}
\hline Approach/study & Unit of analysis & Region & Period of analysis \\
\hline $\begin{array}{l}\text { Jafri and Khattak } \\
\text { (1995) }\end{array}$ & Per capita & $\begin{array}{l}\text { Rural and urban } \\
\text { Pakistan }\end{array}$ & 1979 to $1990 / 91$ \\
\hline Ali (1995) & Per capita & Overall Pakistan & $1990 / 91$ \\
\hline Ahmad (1998) & Adult equivalents & $\begin{array}{l}\text { Rural and urban areas } \\
\text { of each province }\end{array}$ & $\begin{array}{l}\text { 1992/93, 1993/94, } \\
1995 / 96\end{array}$ \\
\hline $\begin{array}{l}\text { Qureshi and Arif } \\
(2001)\end{array}$ & Per capita & $\begin{array}{l}\text { Rural and urban } \\
\text { Pakistan }\end{array}$ & $1998 / 99$ \\
\hline Ashraf (2013) & Adult equivalents & $\begin{array}{l}\text { Rural and urban areas } \\
\text { of each province }\end{array}$ & $2010 / 11$ \\
\hline $\begin{array}{l}\text { Pakistan, Ministry } \\
\text { of Finance }(2016)^{*}\end{array}$ & Adult equivalents & Overall Pakistan & $2013 / 14$ \\
\hline
\end{tabular}

Note: ${ }^{*}=$ new methodology based on reduced reference group.

As discussed above, the calorie intake approach overlooks other nonfood essentials. Thus, embedding nonfood needs into calorie intakes gives us the more scientific basic needs approach, which yields relatively comprehensive data on poverty lines. Malik (1988), Jafri and Khattak (1995), and Qureshi and Arif (2001) use this approach to establish a threshold for measuring poverty lines. In the earlier literature, the unit of analysis was normally per capita or adult equivalent. The per capita measure assigns an equal weight to all household members irrespective of their age and gender. The adult equivalent measure, on the other hand, incorporates age and gender and is thus considered more realistic.

The overview above reveals that most earlier studies have focused merely on the rural-urban divide: very few have tried to estimate poverty lines with provincial distinctions. In this regard, the present study attempts to estimate ten region-specific poverty lines for the rural and urban segments of each province and the capital territory of Islamabad.

\section{Methodological Issues and Analytical Framework}

This section examines the methodological issues associated with estimating poverty lines and measuring poverty.

\subsection{Unit of Wellbeing}

The first step concerns the selection of an indicator of economic wellbeing, with income and expenditure being our two main choices. We consider expenditure, as it is more relevant to poverty analysis. The consumption expenditures reported in the HIES enable us to calculate food 
and nonfood poverty lines separately. ${ }^{3}$ Household expenditure, as defined by the HIES, refers to all money expenditure by the household or by its individual members on goods intended for consumption and on services. Also included is the value of goods and services received in kind and consumed, or self-produced and consumed by the household. Household consumption expenditure is calculated by taking the sum of the following yearly expenditure components:

- Expenditure on food items

- Value of self-produced, self-consumed food items

- Expenditure on nondurable goods and services

- Value of self-produced, self-consumed nondurable goods and services

- Consumption expenditure on durable goods and services

- Value of self-produced, self-consumed durable goods and services

- Value of in-kind consumed wages and salaries

\subsection{Unit of Analysis}

There are two main units of analysis. The first is per capita consumption, which treats all individuals equally. This kind of analysis may be misleading because nutritional requirements often vary with age and gender. A better approach is that of adult equivalence in which each individual is expressed as a fraction of an adult male. ${ }^{4}$ Following Qureshi and Arif (2001), Arshad and Idrees (2008) and Mahmood and Idrees (2010), we use a calorie intake requirement chart to calculate adult-equivalents (see Table A1 in the Appendix).

\subsection{Defining the Poverty Line}

The present study estimates an absolute poverty line indicating the minimum acceptable living conditions, based on nutritional and other

\footnotetext{
${ }^{3}$ The Pakistan Bureau of Statistics ensures the reliability of HIES data through three-stage verification. At the first stage, the enumerator's work is certified by a field supervisor. At the second stage, the consistency of the data is analyzed by field staff at a regional field office. At the final stage, teams at the headquarters thoroughly review and edit the questionnaire to check for inconsistency or omissions. In case the questionnaire requires further clarification or has not been properly filled, the household is revisited to maintain the quality of the data (for details, see http://www.pbs.gov.pk/sites/default/files/ pslm/publications/hies2013_14/HIES_2013-14_18_03_2015.pdf).

${ }^{4}$ For a detailed discussion of the unit of analysis, see Mahmood and Idrees (2010).
} 
basic (nonfood) requirements. ${ }^{5}$ This is known as the basic needs approach, an advantage of which is that it considers both food and nonfood needs. Numerous studies, including Malik (1988), Havinga et al. (1989) and Qureshi and Arif (2001) use this approach to estimate the poverty line. The poverty line thus comprises a food poverty line and nonfood poverty line. We estimate food poverty as the estimated cost of food consistent with the minimum required calorie intake for an adult equivalent. Following Greer and Thorbecke (1986), Ahmed (1991), Ercelawn (1991) and Qureshi and Arif (2001), the given calorie cost function is estimated to determine the food poverty line:

$$
\ln X=a+b C+u
$$

where $X$ is the expenditure on the food basket consumed by an individual, $C$ is the number of calories that an individual derives from this food basket and $u$ is the error term.

Basic needs also include nonfood needs such as shelter, clothing and healthcare. In this respect, the simplest approach is to consider the 10 percent of households whose food expenditures lie between 95 and 105 percent of the food poverty line, and then calculate the weighted average of their nonfood expenditures to obtain a nonfood poverty line. The weighting scheme is as follows: 99-101 percent is given a weight of 5/15, 98-99 percent and 101-102 percent are given a weight of 4/15, 97-98 percent and 102-103 percent are given a weight of 3/15, 96-97 percent and 103-104 percent are given a weight of 2/15. Finally, 95-96 percent and 104105 percent are given a weight of 1/15 (Ravallion, 1994, 1998). ${ }^{6}$

This method of calculating the nonfood component has been used by many studies, including White and Masset (2003) and Qureshi and Arif (2001). The rationale for this approach is that households on the edge of the food poverty line spend only on essential nonfood items. Thus, such expenditures can be considered the minimum nonfood items needed to escape poverty. The HIES (2013/14) data also supports this argument. We

\footnotetext{
${ }^{5}$ Relative poverty defines the poverty line in relation to the average standard of living enjoyed by society (Kakwani, 2001) and thus does not take into account minimum living standards. Rather, it considers those individuals whose living standards are low relative to the rest of society. The subjective poverty line is based on the individual's preferences concerning a minimum income or expenditure. Of these three approaches, the absolute poverty line is considered the best as it calculates the minimum consumption expenditure needed to escape poverty.

${ }^{6}$ Instead of using food expenditures, many studies, including Ravallion (1994, 1998), Ravallion and Bidani (1994) and Mukherjee and Benson (2003), use total expenditures, which lie around \pm 5 percent of the food poverty line.
} 
find that the households falling in this range spend very little under heads such as medical care, transport and communication, recreation, education, garments, hoteling and personal appearance.

\subsection{Measuring Poverty}

Having estimated the poverty line, the next step is to gauge the extent of poverty, the most common measure of which is the headcount index introduced by Rowntree (1901). Since then, a large body of literature has developed on various measures of poverty. Selecting the best poverty measure is based on a range of desirable properties, as outlined in Figure 2 (see also the Appendix).

\section{Figure 2: Desirable properties of a good poverty measure}

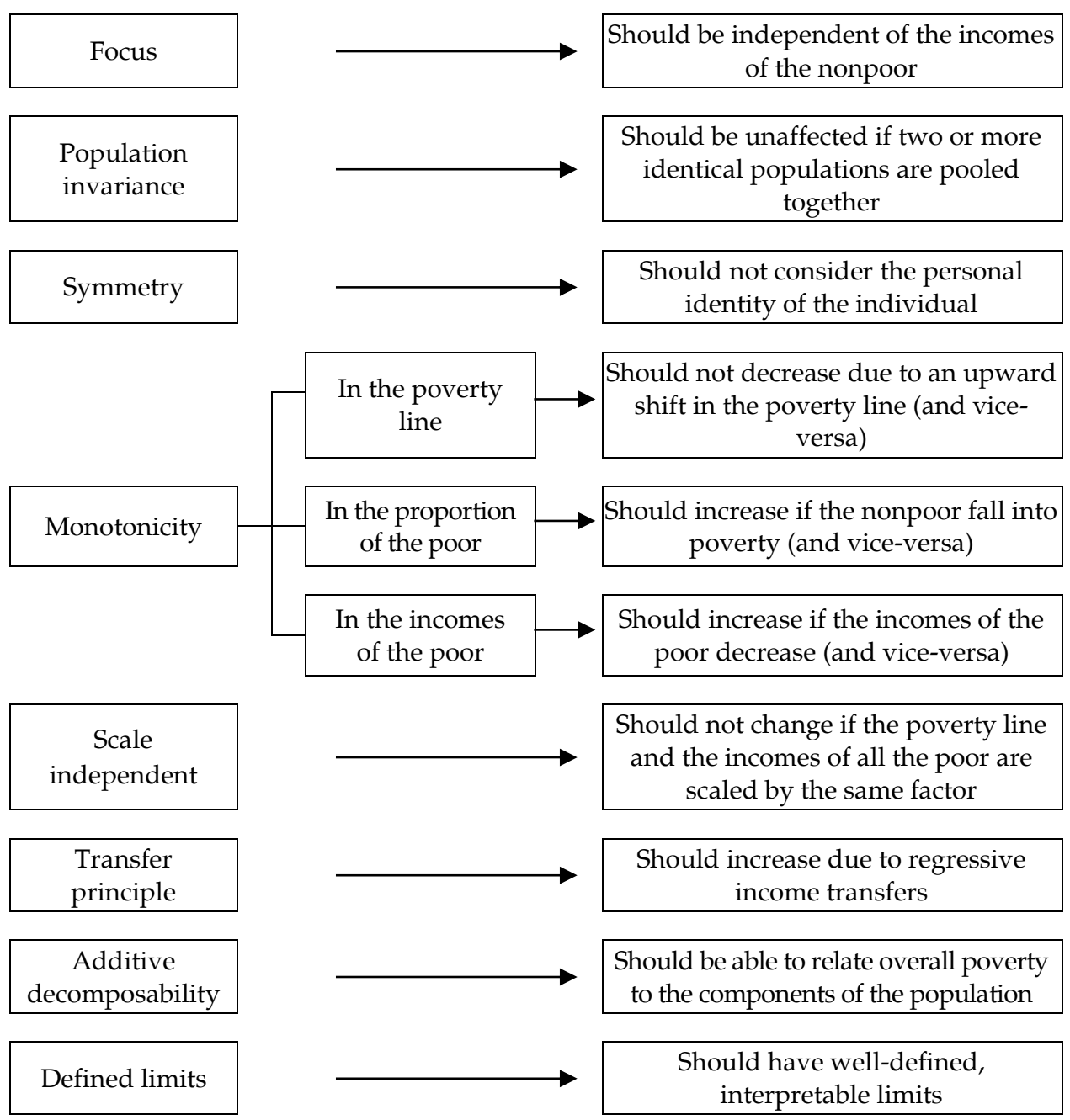


The headcount index, poverty gap index and squared poverty gap index are the most commonly used measures, which fulfill most of the properties listed above, including focus, symmetry, scale independence, decomposability, monotonicity in poverty lines and monotonicity in the proportion of the poor. However, the headcount index and poverty gap index do not satisfy the transfer axiom. The squared poverty gap index is responsive to income redistributions among the poor, but does not have defined, interpretable limits. The present study calculates poverty using these three measures, as each looks at a different dimension of poverty. A brief description of each is given in Table 2.7

Table 2: Headcount index, poverty gap and squared poverty gap

\begin{tabular}{|c|c|c|}
\hline Measure & Formula & Definition and features \\
\hline $\begin{array}{l}\text { Headcount } \\
\text { index }\end{array}$ & $P_{o}=\frac{N_{P}}{N}$ & $\begin{array}{l}\text { - Proportion of the population below } \\
\text { the poverty threshold level } \\
\text { - } 0 \leq P_{o} \leq 1 \\
\text { - Fails to account for the intensity of } \\
\text { poverty } \\
\text { - Conditionally satisfies the principle } \\
\text { of transfer } \\
\text { - Insensitive to income transfers } \\
\text { within the poor }\end{array}$ \\
\hline $\begin{array}{l}\text { Poverty gap } \\
\text { index }\end{array}$ & $P_{1}=\frac{1}{N} \sum_{i=0}^{N_{P}}\left(\frac{g_{P}}{z}\right)=\frac{1}{N z} \sum_{i=0}^{N_{P}}\left(g_{P}\right)$ & $\begin{array}{l}\text { - Captures the extent to which } \\
\text { individuals fall below poverty line } \\
\text { and expresses it as a percentage of } \\
\text { poverty line } \\
\text { - } 0 \leq P_{o} \leq 1 \\
\text { - Insensitive to income transfers } \\
\text { within the poor }\end{array}$ \\
\hline $\begin{array}{l}\text { Squared } \\
\text { poverty gap } \\
\text { index }\end{array}$ & $P_{2}=\frac{1}{N} \sum_{i=0}^{N_{P}}\left(\frac{g_{P}}{z}\right)^{2}$ & $\begin{array}{l}\text { - Weighted sum of poverty gaps as a } \\
\text { proportion of poverty line, where } \\
\text { the weights are the poverty gaps } \\
\text { themselves } \\
\text { - Sensitive to income transfers within } \\
\text { the poor } \\
\text { - } 0 \leq P_{o} \leq \infty\end{array}$ \\
\hline
\end{tabular}

Note: $N_{P}=$ the number of poor, $N=$ total population, $z=$ the poverty line, $g_{P}=$ income gap $\left(z-Y_{P}\right)$ such that $z \geq Y_{P}$.

${ }^{7} P_{0}, P_{1}$ and $P_{2}$ are limiting cases of FGT indices (Foster, Greer \& Thorbecke, 1984). These are expressed as $P_{\alpha}=\frac{1}{N} \sum_{i=0}^{N_{P}}\left(\frac{g_{P}}{z}\right)^{\alpha}$ where $\alpha$ is the poverty aversion parameter and can be interpreted as the weight given to the poor. With $\alpha$ equal to 0 , the index becomes $P_{0}$, implying that the income shortfalls of the poverty line are given no weight. With $\alpha$ equal to 1 , the index becomes $P_{1}$, implying that the income shortfalls of the poverty line are given equal weight. Finally, with $\alpha$ equal to 2 , the index becomes $P_{2}$, implying that the income shortfall of the poverty line is weighted by itself. 
The first measure, the headcount index, gives the proportion of households below the poverty line, although it fails to measure the intensity of poverty. The second measure is the poverty gap index, which covers this drawback by considering the extent of poverty and expressing it as a percentage of the poverty line. A problem with the poverty gap index is that it does not consider redistributions of income within the poor, but this shortcoming is resolved by the squared poverty gap.

\subsection{Regional Distribution of Poverty}

The study has a twofold objective: first, to estimate regional poverty lines and, second, to measure the magnitude and extent of poverty in each region. Having estimated the regional poverty lines and measured poverty in each region, the next task is to determine how regional poverty contributes to overall poverty in Pakistan and thus gauge national estimates of poverty. This is done by aggregating the regional poverty lines and regional poverty levels as follows:

The aggregation of poverty lines is denoted by

$$
P_{L}=\sum_{i=1}^{k}\left(s_{i} P_{L i}\right)
$$

where $P_{L}$ is the aggregate poverty line taken as the weighted average of the regional poverty lines $\left(P_{L i}\right)$. The weights are the population shares $\left(s_{i}\right)$.

The aggregation of poverty estimates is denoted by

$$
P_{O}=\sum_{i=1}^{k}\left(s_{i} P_{o i}\right)
$$

where $P_{O}$ is the overall proportion of poor households, $s_{i}$ is the population share of poor households belonging to the $i$ th region and $P_{o i}$ is the headcount index in the $i$ th region.

\section{Results and Discussion}

This section presents the food and nonfood poverty line estimates for all five regions, followed by a discussion of the extent and intensity of poverty in each region and the results based on the distribution of poverty. 


\subsection{Estimation of Regional Poverty Lines}

The estimates of the food and nonfood poverty lines for the rural and urban segments of each province and Islamabad Capital Territory are presented in Table 3. The food poverty line estimates show that, with the exception of the federal capital territory, the urban poverty line is higher than the rural poverty line in all regions. While food requirements do not vary considerably across rural and urban areas, the difference is in part due to the cost of a basic food bundle. Food items, especially cereals, milk, vegetables, fruit, pulses and meat, tend to be cheaper in rural areas.

Table 3: Estimates of regional food, nonfood and overall poverty lines

\begin{tabular}{llrrr}
\hline \multirow{2}{*}{ Region } & & \multicolumn{3}{c}{ Per adult equivalent poverty lines } \\
\cline { 3 - 5 } Punjab & & Food & Nonfood & Overall \\
\cline { 3 - 5 } Sindh & Rural & $1,931.76$ & 920.29 & $2,852.05$ \\
& Urban & $2,112.57$ & $1,080.34$ & $3,192.91$ \\
KP & Rural & $1,876.65$ & 759.74 & $2,636.39$ \\
& Urban & $2,297.85$ & $1,200.92$ & $3,498.77$ \\
Balochistan & Rural & $2,165.43$ & $1,001.43$ & $3,166.86$ \\
& Urban & $2,238.22$ & $1,010.03$ & $3,248.25$ \\
Islamabad Capital Territory & Rural & $1,714.48$ & 851.04 & $2,565.52$ \\
& Urban & $1,783.96$ & 913.16 & $2,697.12$ \\
& Rural & $3,136.72$ & $1,605.59$ & $4,742.31$ \\
& Urban & $2,752.30$ & $1,390.51$ & $4,142.81$ \\
\hline
\end{tabular}

Also, the HIES data for 2013/14 shows that the average price of basic food items, including wheat, wheat flour, rice, rice flour and milk, is about 5 percent lower in rural areas relative to urban areas. Moreover, in rural areas, 37.75 percent of these products come under the category of 'own produced and consumed'. There may also be a difference in consumption bundles, as people in rural areas are less likely to consume readymade and fast foods, which are relatively more expensive.

A different picture surfaces in Islamabad where the food poverty line for rural areas is higher than that for urban areas. A possible reason is that the rural areas of Islamabad do not practice extensive farming and that most of the cereals, meat, vegetables, fruit and milk consumed are supplied from other regions of the country. Moreover, households in rural Islamabad tend to travel to urban areas to purchase food and other essentials. The provincial comparison reveals that the food poverty line is lowest in Sindh, followed by Punjab and Balochistan. This indicates that 
the cost of living is relatively low in Sindh and Punjab, which could be due to the strong agrarian economy in both provinces.

The estimated nonfood poverty lines follow similar trends, although the magnitude of nonfood poverty expenditures is about half that of food poverty. This is understandable, as the main expenditures of poor and low-income households are food items. The overall poverty lines, which are the sum of the food and nonfood poverty lines, follow a similar pattern.

\subsection{Measurement of Regional Poverty}

To measure regional poverty, we estimate the headcount indices (P0), poverty gap (P1) and squared poverty gap (P2) at the household level, i.e., what proportion of households are poor and what is the depth of poverty. This entails comparing per adult-equivalent household average expenditures with the poverty line, such that households falling short of the poverty line are treated as poor. Next, we consider the number of adultequivalents in each household and express the poverty estimates in terms of adult-equivalents rather than households (Table 4).

Table 4: Measurement of regional poverty in Pakistan

\begin{tabular}{llcccccc}
\hline Region & & \multicolumn{3}{c}{$\begin{array}{c}\text { Poverty measured in } \\
\text { terms of households }\end{array}$} & \multicolumn{3}{c}{$\begin{array}{c}\text { Poverty measured in } \\
\text { terms poor adult } \\
\text { equivalents }\end{array}$} \\
\cline { 3 - 8 } & & P0 & P1 & P2 & P0 & P1 & P2 \\
\hline Punjab & Rural & 0.216 & 0.055 & 0.022 & 0.274 & 0.077 & 0.320 \\
& Urban & 0.150 & 0.030 & 0.010 & 0.197 & 0.043 & 0.139 \\
Sindh & Rural & 0.365 & 0.113 & 0.048 & 0.498 & 0.168 & 0.774 \\
& Urban & 0.257 & 0.060 & 0.025 & 0.371 & 0.097 & 0.432 \\
KP & Rural & 0.198 & 0.031 & 0.008 & 0.271 & 0.045 & 0.150 \\
& Urban & 0.138 & 0.021 & 0.005 & 0.180 & 0.026 & 0.058 \\
Balochistan & Rural & 0.334 & 0.095 & 0.038 & 0.451 & 0.139 & 0.824 \\
& Urban & 0.257 & 0.107 & 0.050 & 0.389 & 0.172 & 1.315 \\
Islamabad & Rural & 0.154 & 0.036 & 0.011 & 0.248 & 0.067 & 0.212 \\
Capital Territory & Urban & 0.241 & 0.033 & 0.027 & 0.367 & 0.061 & 0.458 \\
\hline
\end{tabular}

The estimates of poverty in terms of households show that, with the exception of Islamabad Capital Territory, rural poverty in all the regions is more pronounced. This is interesting because it shows that, despite lower poverty lines, a larger proportion of rural households are poor. In turn, this indicates that general living standards are low in rural areas. This is 
reflected in the data on average earnings and the proportion of the employed population. According to the HIES (2013/14), average earnings in urban areas are 50 percent greater than those in rural areas. Similarly, the proportion of the employed population (aged 15 or above and currently not enrolled) in urban areas is 10 percent higher relative to rural areas.

The statistics also reveal that the incidence of poverty is far higher in Sindh and Balochistan. This is understandable, given that feudalism and the vadera system are much stronger in both provinces. ${ }^{8}$ The disaggregated data reveals that more that 40 percent of farmers in Sindh and Balochistan do not own agricultural land and thus work as vassals. Moreover, Sindh experienced heavy floods in 2012, which had an adverse effect on its agricultural output and thus reduced the earnings of small tenants, which in turn led to an increase in poverty in rural Sindh. It is interesting to note that the estimates of the poverty gap (P0) and squared poverty gap (P1) follow a similar pattern, indicating that regions with greater poverty experience extensive poverty, while regions with lower poverty experience less extensive poverty. These findings are consistent with Arif et al. (2016) and Jamal (2017).

The household-level poverty estimates look at the proportion of poor households and their depth of poverty, but ignore household size. Since incorporating household size gives a more accurate picture of poverty, we re-estimate the headcount indices by expressing the number of adult-equivalents belonging to poor households as a proportion of the total number of adult-equivalents. Similarly, we readjust the poverty gap and squared poverty gap for household size.

While the estimates of poverty per adult-equivalent follow a similar pattern to the household-level estimates, the former present a more alarming picture. For instance, 36.5 percent of poor households in rural Sindh comprise 49.8 percent of the total population (measured in terms of adult-equivalents). A similar phenomenon is observed in the other regions. Poverty measured in terms of households reflects that urban KP is the least poor region - 13.8 percent of households are reported to be poor - but this figure jumps to 18 percent when reestimated in terms of population. Thus, incorporating household size portrays the actual state of poverty overall and indicates that poor households tend to be larger than nonpoor households.

\footnotetext{
${ }^{8}$ Under this system, landlords own large tracts of land farmed by small tenants, who often live at subsistence level. Perveen and Dasti (2014), Anwar, Qureshi and Ali (2004) and the Asian Development Bank (2002) argue that feudalism is closely linked to large-scale poverty in Pakistan.
} 


\subsection{Regional Distribution of Poverty}

Having estimated the region-specific poverty lines and poverty in the rural and urban segments of each province/region, we now assess how poverty in each region contributes to overall poverty in Pakistan and develop estimates of rural, urban and national poverty lines. Aggregating these poverty lines will help gauge the extent of poverty in Pakistan. Finally, we shall also attempt to analyze poverty differentials across ruralurban segments.

\subsubsection{Aggregation of Poverty Lines to Obtain National Poverty Lines}

The national poverty line is estimated as the weighted average of the regional poverty lines, where the weights are the population shares of each region. The aggregation of the regional poverty lines is presented in Figure 3. The rural poverty line of each region is given at the top of the figure. Each poverty line is then multiplied by the population share of that region. This gives us the rural poverty line for Pakistan. The urban poverty lines are reported at the bottom of the figure and obtained the same way. Finally, the weighted average of the rural and urban poverty lines gives us the national poverty line.

Figure 3: Aggregation of regional poverty lines

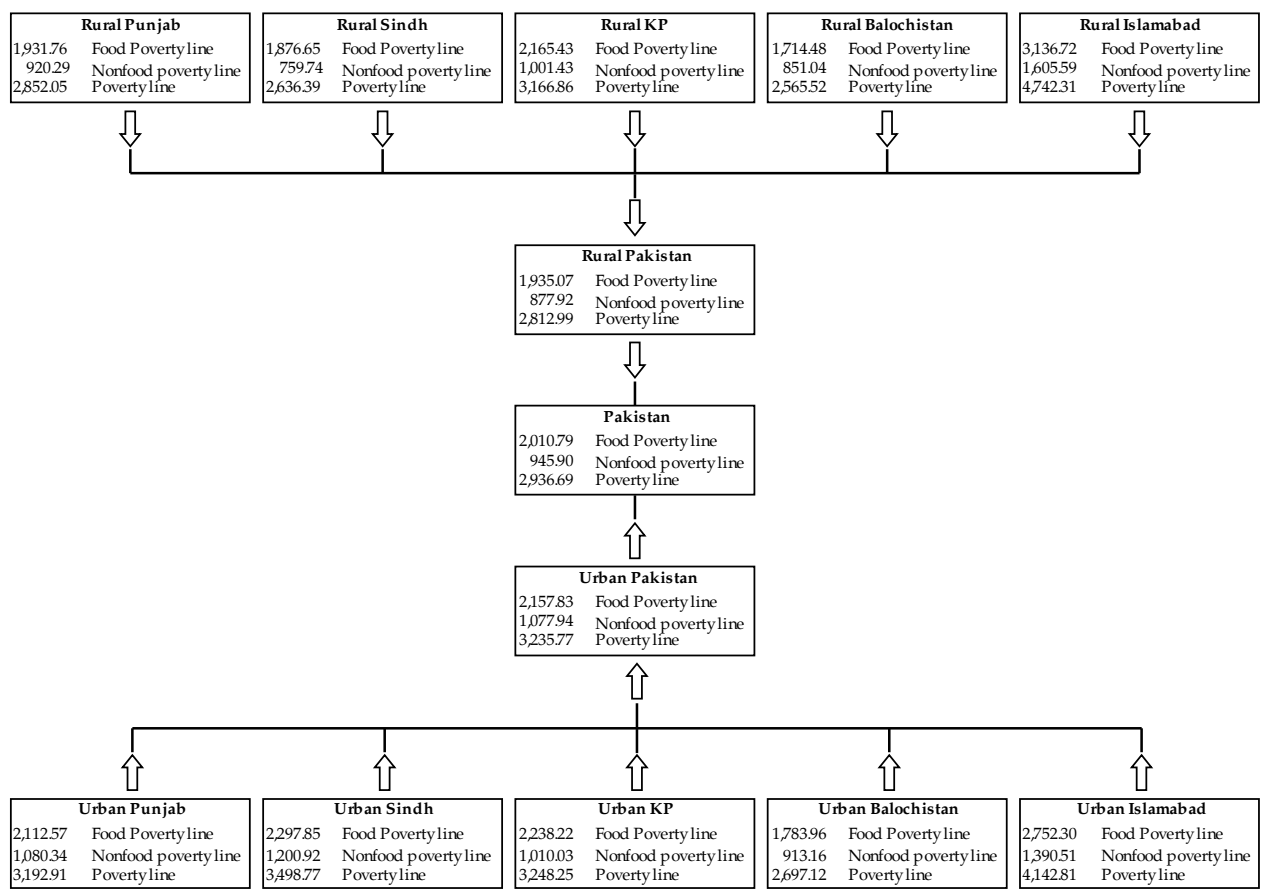


The poverty line for rural Pakistan is PKRs2,812.99 per adultequivalent (monthly expenditure). For urban areas, it is PKRs3,235.77, which indicates that the cost of maintaining a subsistence level is about 15 percent higher in urban areas. The national poverty line is PKRs2,956.69 per adult-equivalent (monthly expenditure) and is closer to the rural poverty line because 66 percent of the population lives in rural areas. It is worth mentioning that national rural and urban poverty lines do not provide a useful measure of poverty for any specific region of the country. For instance, whereas the national poverty line is PKRs2,956.69, the poverty line for rural KP is PKRs3,166.86. Thus, a household in rural KP with a per adult-equivalent expenditure between these two figures is classified as 'poor' according to the rural poverty line for KP, but 'nonpoor' according to the national poverty line. Aggregation is, therefore, of limited use and can be misleading. To accurately measure poverty, we need to rely on region-specific poverty lines.

\subsubsection{Aggregation of Headcount Indices}

The aggregation of the regional headcount indices is presented in Figure 4. The headcount index, if defined in terms of adult-equivalents (population), is 0.368 for rural Pakistan, indicating that about 37 percent of the rural population is poor. The urban statistics are better, but not satisfactory, with about 25 percent of the population living below the poverty line. The headcount index for national poverty shows that almost a third of the population falls below the poverty line. 
Figure 4: Aggregation of headcount indices measured in terms of households and adult equivalents/population



The Government of Pakistan has increased allocations for social safety net programs such as the Benazir Income Support Program, Pakistan Poverty Alleviation Fund, Waseela-e-Taleem, Apna Rozgar Scheme, Prime Minister's Youth Business Loan and Yellow Cab Scheme. The budgetary allocation to poverty alleviation programs between 2010/11 and 2013/14 was PKRs7,299,397 million - on average equal to 12.9 percent of each year's GDP. However, the continuing high poverty level indicates that the effect of these policies has been limited and far more needs to be done to alleviate poverty.

There may be several reasons for the low impact of these programs. Shirazi and Obaidullah (2014), for instance, point out that the lack of coordination among the agencies managing different safety net programs leads to the duplication of funds at the expense of deserving households. Another reason is the flawed distribution system. For instance, zakat is often distributed on the recommendation of local councilors, politicians and other influential persons, which implies that it does not necessarily reach the most deserving. Arif (2006) notes that, in rural areas, 42 percent of zakat recipients were selected based on the same flawed mechanism. Nayab and Farooq (2014) analyze the effectiveness of the Benazir Income 
Support Program and observe that many households receiving continual support are no longer under the poverty line. Hence, imperfect targeting is a key constraint to making these polices more effective.

High inflation is another possible cause of poverty in Pakistan, as it acts as a regressive tax by reducing purchasing power. On average, fixedsalary individuals and low-income households are adversely affected by inflation. During 2010/11 to 2013/14, the average annual inflation rate remained in double digits, which further eroded the purchasing power of low-income households. Different studies, including Braumann (2004), Chaudhry and Chaudhry (2008) and Aftab et al. (2015), argue that inflation adversely affects poverty.

Apart from social and economic factors, individual characteristics such as lack of skills, illiteracy and large households are also associated with poverty. A disaggregated analysis of poor households reveals that about two thirds of household heads are either illiterate or have not even completed primary school. Likewise, 44 percent of poor households have eight or more adult-equivalents, while most poor workers tend to be unskilled (HIES 2013/14). ${ }^{9}$

\section{Conclusion}

A significant proportion of the population in Pakistan still lives below the poverty line. ${ }^{10}$ While most earlier studies have used a single poverty line for the whole country or relied on rural-urban divides, this segmentation fails to incorporate differences across provinces. The present paper attempts to bridge the gap in the literature by estimating region/province-specific poverty lines for the rural and urban segments of each province and the capital territory of Islamabad.

The paper's estimated food poverty lines show that, barring Islamabad, the urban poverty line is higher in all regions - a possible reason being the higher cost of the basic food bundle. A provincial comparison reveals that the food poverty line is lowest in Sindh, followed by Punjab and Balochistan. This indicates that the cost of living is relatively

\footnotetext{
${ }^{9}$ In nonpoor households, 46 percent of household heads are illiterate or did not complete primary school, 21 percent of households have eight or more adult-equivalents and a significant proportion of workers are skilled or semi-skilled.

${ }^{10}$ In terms of the population below the poverty line, the World Development Indicators show that, between 2013 and 2015, Pakistan was among the bottom 29 countries out of 81 (for which data was available). If we consider the data for 2007 to 2015, then Pakistan falls among the bottom 42 out of 121 countries.
} 
low in Sindh and Punjab, which may be due to their strong agrarian base. While the estimated nonfood poverty lines follow similar trends, the magnitude of nonfood poverty is about half that of food poverty.

The paper also measures the magnitude and extent of poverty in each region, using headcount indices, poverty gap indices and squared poverty gap indices. We find that poverty estimates in terms of households ignore household size and thus suppress poverty figures. Our estimates show that, with the exception of Islamabad Capital Territory, rural poverty is far more pronounced than urban poverty in all regions. The statistics also reveal that the incidence of poverty is higher in Sindh and Balochistan.

It is interesting to note that the estimates of the poverty gap and squared poverty gap follow a similar pattern, indicating that regions with greater poverty experience extensive poverty while those with lower poverty experience less extensive poverty. In areas such as rural Sindh and Balochistan, more effective policies are needed to counter the effects of feudalism. The government should initiate separate safety nets for poor tenants in these provinces with more emphasis on skills development.

The national poverty line is estimated as the weighted average of the regional poverty lines, equal to PKRs2,956.69 per adult-equivalent (monthly expenditure). The statistics show that about 37 percent of the rural population is poor. The urban statistics are better, but not satisfactory: about 25 percent of the population still lives below the poverty line. The headcount index for Pakistan shows that almost a third of the population falls below the poverty line.

Despite allocating significant funds to social safety net programs, poverty has not declined enough. Part of this is due to the flaws inherent in such programs, such as political influence in the distribution of funds and lack of coordination among the agencies managing different safety net programs. These flaws could be removed though proper planning and management. All schemes could also be better integrated and target the poor more effectively. Finally, a more focused policy to enhance the skills of poor labor is needed, as most households trapped in poverty suffer from a lack of skills.

This study empirically analyzes poverty in the rural and urban segments of each province and the capital territory of Islamabad. Future research at the district level could help uncover the disparities within each province. 


\section{References}

Aftab, M. R., Rehman, M., Chaudhary, A. R., \& Faheem, M. (2015). Food prices and its impact on poverty in Pakistan. Pakistan Journal of Social Sciences, 35(2), 903-910.

Ahmad, E., \& Ludlow, S. (1989). Poverty, inequality and growth in Pakistan. Pakistan Development Review, 28(4), 831-850.

Ahmad, N. (1998). Poverty in Pakistan. Pakistan Journal of Applied Economics, 14(1-2), 1-26.

Ahmed, T. U. (1991). Poverty in Bangladesh. In Proceedings of the workshop on dissemination of current statistics. Dhaka: Bangladesh Bureau of Statistics.

Alauddin, T. (1975). Mass poverty in Pakistan: A further study. Pakistan Development Review, 14(4), 431-450.

Ali, M. S. (1995). Poverty assessment: Pakistan's case. Pakistan Development Review, 34(1), 43-54.

Anwar, T. (2005). Prevalence of relative poverty in Pakistan. Pakistan Development Review, 44(4), 1111-1131.

Anwar, T. (2006). Trends in absolute poverty and governance in Pakistan: 1998-99 and 2004-05. Pakistan Development Review, 45(4), 777-793.

Anwar, T. (2010). Role of growth and inequality in explaining changes in poverty in Pakistan. Pakistan Development Review, 49(1), 1-17.

Anwar, T., \& Qureshi, S. K. (2002). Trends in absolute poverty in Pakistan: 1990-91 and 2001. Pakistan Development Review, 41(4), 859-878.

Anwar, T., Qureshi, S. K., \& Ali, H. (2004). Landlessness and rural poverty in Pakistan. Pakistan Development Review, 43(4), 855-874.

Arif, G. M. (2006). Targeting efficiency of poverty reduction programs in Pakistan (Working Paper No. 4). Islamabad: Asian Development Bank.

Arshad, H., \& Idrees, M. (2008). Trends in polarization in Pakistan. Pakistan Development Review, 47(2), 153-167. 
Ashraf, S. (2013). Poverty profile of Pakistan. Unpublished MPhil thesis, Quaid-i-Azam University, Islamabad.

Asian Development Bank. (2002). Poverty in Pakistan: Issues, causes and institutional responses (Report No. 24296-PAK). Islamabad: Author.

Braumann, B. (2004). High inflation and real wages. IMF Staff Papers, 51(1), 123-147.

Castelló-Climent, A. (2010). Inequality and growth in advanced economies: An empirical investigation. Journal of Economic Inequality, 8(3), 293-321.

Chaudhry, T. T., \& Chaudhry, A. A. (2008). The effects of rising food and fuel costs on poverty in Pakistan. Lahore Journal of Economics, 13, 117-138.

De Kruijk, H., \& Van Leeuwen, M. (1985). Changes in poverty and income inequality in Pakistan during the 1970s. Pakistan Development Review, 24(3-4), 407-419.

Ercelawn, A. A. (1990). Absolute poverty in Pakistan: Poverty lines, incidence, intensity. Unpublished manuscript, Applied Economics Research Centre, Karachi.

Ercelawn, A. A. (1991). Absolute poverty as risk of hunger: Norms, incidence, and intensity for rural and urban Pakistan. Unpublished manuscript, Applied Economics Research Centre, Karachi.

Forbes, K. J. (2000). A reassessment of the relationship between inequality and growth. American Economic Review, 90(4), 869-887.

Foster, J., Greer, J., \& Thorbecke, E. (1984). A class of decomposable poverty measures. Econometrica, 52(3), 761-766.

Greer, J., \& Thorbecke, E. (1986). A methodology for measuring food poverty applied to Kenya. Journal of Development Economics, 24(1), 59-74.

Halter, D., Oechslin, M., \& Zweimüller, J. (2014). Inequality and growth: The neglected time dimension. Journal of Economic Growth, 19(1), 81-104 
Havinga, I. C., Haanappel, F. W., Louter, A. S., \& van den Andel, W. A. (1989). Poverty in Pakistan 1984-1985. Pakistan Development Review, 28(4), 851-869.

Irfan, M., \& Amjad, R. (1984). Poverty in rural Pakistan. In A. R. Khan \& E. Lee (eds.), Poverty in rural Asia (pp. 19-47). Bangkok: ILO ARTEP.

Jafri, S. M. Y., \& Khattak, A. (1995). Income inequality and poverty in Pakistan. Pakistan Economic and Social Review, 33(1-2), 37-58.

Jamal, H. (2002). On the estimation of an absolute poverty line: An empirical appraisal. Lahore Journal of Economics, 7(2), 77-91.

Jamal, H. (2005). In search of poverty predictors: The case of urban and rural Pakistan. Pakistan Development Review, 44(1), 37-55.

Jamal, H. (2017). Poverty and vulnerability estimates: Pakistan, 2016 (Research Report No. 99). Karachi: Social Policy and Development Centre.

Jan, D., Chishti, A., \& Eberle, P. (2008, July). An analysis of major determinants of poverty in agriculture sector in Pakistan. Paper presented at the Annual Meeting of the American Agricultural Economics Association, Orlando, FL.

Kakwani, N. (2001, February). On specifying poverty lines. Paper presented at the Asia and Pacific Forum on Poverty: Reforming Policies and Institutions for Poverty Reduction, Asian Development Bank, Manila.

Mogstad, M., Langørgen, A., \& Aaberge, R. (2007). Region-specific versus country-specific poverty lines in analysis of poverty. Journal of Economic Inequality, 5(1), 115-122.

Mahmood, R., \& Idrees, M. (2010). Income polarization in Pakistan: Measurement and decomposition. Pakistan Economic and Social Review, 48(2), 225-244.

Mahmood, S., Sheikh, K. H., \& Mahmood, T. (1991). Food poverty and its causes in Pakistan. Pakistan Development Review, 30(4), 821-834.

Malik, M. H. (1988). Some new evidence on the incidence of poverty in Pakistan. Pakistan Development Review, 27(4), 509-515. 
Mukherjee, S., \& Benson, T. (2003). The determinants of poverty in Malawi, 1998. World Development, 31(2), 339-358.

Naseem, S. M. (1973). Mass poverty in Pakistan: Some preliminary findings. Pakistan Development Review, 12(4), 317-360.

Naseem, S. M. (1977). Rural poverty and landlessness in Pakistan. In K. Griffin \& A. R. Khan (eds.), Poverty and landlessness in rural Asia (pp. 41-60). Geneva: ILO.

Nayab, D., \& Farooq, S. (2014). Effectiveness of cash transfer programmes for household welfare in Pakistan: The case of the Benazir Income Support Programme. Pakistan Development Review, 53(2), 145-174.

Neves, P. C., \& Silva, S. M. T. (2014). Inequality and growth: Uncovering the main conclusions from the empirics. Journal of Development Studies, 50(1), 1-21.

Pakistan, Ministry of Finance. (2003). Accelerating economic growth and reducing poverty: The road ahead. Islamabad: Author.

Pakistan, Ministry of Finance. (2016). Pakistan economic survey 2015-16. Islamabad: Author.

Perveen, S., \& Dasti, H. A. (2014). Feudalism: A pastime of power, economic and political influence in Pakistan. Pakistan Vision, 15(1), 59-75.

Qureshi, S. K., \& Arif, G. M. (2001). Poverty profile in Pakistan: 1998-99 (MIMAP Technical Paper No. 5). Islamabad: Pakistan Institute of Development Economics.

Ravallion, M. (1994). Poverty comparisons. Chur, Switzerland: Harwood Academic Press.

Ravallion, M. (1998). Poverty lines in theory and practice: Living Standards Measurement Study (LSM Working Paper No. 133). Washington, DC: World Bank.

Ravallion, M., \& Bidani, B. (1994). How robust is a poverty profile? World Bank Economic Review, 8(1), 75-102.

Rowntree, B. S. (1901). Poverty: A study of town life. London: Macmillan. 
Shirazi, N. S., \& Obaidullah, M. (2014). Why poverty reduction programs of Pakistan did not bring significant change: An appraisal (Working Paper No. 1435-17). Jeddah: Islamic Research and Training Institute.

White, H., \& Masset, E. (2003). Constructing the poverty profile: An illustration of the importance of allowing for household size and composition in the case of Vietnam. Development and Change, 34(1), 105-126.

World Bank. (2017). World development indicators. Available at www.worldbank.org

Zaidi, M. A. (1992). Relative poverty in Pakistan: An estimation from the Household Income and Expenditure Survey (1984-85). Pakistan Development Review, 31(4), 955-974.

Zaidi, M. A., \& De Vos, K. (1993). Research on poverty statistics in Pakistan: Some sensitivity analyses. Pakistan Development Review, 32(4), 1171-1186. 


\section{Appendix}

Table A1: Per day minimum caloric requirements

\begin{tabular}{lcccc}
\hline Age group & Males & Equivalent factor & Females & Equivalent factor \\
\hline Less than a year & 1,010 & 0.4297872340 & 1,010 & 0.4297872340 \\
$01-04$ & 1,304 & 0.5548936170 & 1,304 & 0.5548936170 \\
$05-09$ & 1,768 & 0.7523404255 & 1,768 & 0.7523404255 \\
$10-14$ & 2,816 & 1.1982978723 & 2,464 & 1.0485106383 \\
$15-19$ & 3,087 & 1.3136170213 & 2,322 & 0.9880851064 \\
$20-39$ & 2,760 & 1.1744680851 & 2,080 & 0.8851063830 \\
$40-49$ & 2,640 & 1.1234042553 & 1,976 & 0.8408510638 \\
$50-59$ & 2,460 & 1.0468085106 & 1,872 & 0.7965957447 \\
60 and above & 2,146 & 0.9131914894 & 1,632 & 0.6944680851 \\
National average & 2,350 & 1.0000000000 & & \\
\hline
\end{tabular}

Source: Government of Pakistan (2003).

\section{Desirable properties of a good poverty measure}

- Focus: Focuses solely on the incomes of the poor and is not concerned with the incomes of the nonpoor. Any change in the incomes of the poor should affect poverty and any change in the incomes of the nonpoor should not affect poverty.

- Population invariance: Should be invariant to the replication of populations. For example, merging two or more identical distributions should not alter the poverty measure.

- Symmetry: Should be independent of any characteristics of income units other than the income or welfare indicator being measured.

- Monotonicity in the poverty line: Any upward shift in the poverty line should represent an increase in poverty or leave it unchanged and vice versa.

- Monotonicity in the proportion of the poor: Poverty increases if the proportion of the poor increases and vice versa.

- Monotonicity in the incomes of the poor: Any upward shift in the incomes of the poor should cause a decrease in poverty and vice versa.

- Scale independent: Should be invariant to uniform proportional changes: if each income unit's income and poverty line changes by the same proportion, the value of the poverty measure should not change. 
- Transfer principle: A rank-preserving income transfer from rich to poor or poor to poorer will decrease poverty and vice versa.

- Decomposability: Should be able to analyze the contribution of subpopulations to total poverty, such as how poverty in rural and urban segments contributes to overall poverty in a country.

- Defined limits: Should have defined, interpretable limits independent of population size. A lower limit of 0 reflects no poverty and an upper limit of 1 indicates 100 percent poverty. 